\title{
CITRA DIRI MENURUT KEJADIAN 1:26-27 DAN APLIKASINYA BAGI PENGURUS PEMUDA REMAJA GPDI HEBRON-MALANG
}

\author{
Murni Hermawaty Sitanggang ${ }^{1} \&$ Juantini $^{2}$ \\ Universitas Jember ${ }^{1} \&$ Institut Injili Indonesia ${ }^{2}$ \\ Jl. Kalimantan Kampus Tegalboto Jember ${ }^{1}$ \\ Jl. Trunojoyo No.12, Songgokerto, Kec. Batu, Kota Batu, Jawa Timur $65313^{2}$ \\ Email: murni_hermawaty@yahoo.co.id ${ }^{1}$
}

\begin{abstract}
Murni Hermawaty Sitanggang \& Juantini, Self-Image According to Genesis 1:26-27, The Application for Youth Stewards The Indonesian Pentecostal Church Hebron-Malang. The right understanding about self-image as written in Genesis 1:26-27 will affect someone's way of life. This research tries to prove that with focused on to the Youth Stewards at The Indonesian Pentecostal Church Hebron-Malang. The research used a qualitative method with a descriptive and exegetical approach. The result is most of the ministers do not have the right self-image as Genesis 1:26-27 said yet. From the religious side, their self-image is low with $36,5 \%$ score, and from the psychological side they score $45,9 \%$ and then from the social side the result is $55,5 \%$.
\end{abstract}

Key Words: up to 8 words, better to just 5 words.

\begin{abstract}
Abstrak: Murni Hermawaty Sitanggang \& Juantini, Citra Diri Menurut Kejadian 1:26-27, dan Aplikasinya bagi Pengurus Pemuda Remaja GPdI Hebron-Malang. Pengertian yang benar tentang citra diri manusia sebagaimana tertulis dalam Kejadian 1:26-27 akan mempengaruhi cara hidup seseorang. Penelitian ini berusaha membuktikan hal tersebut dengan memfokuskan sasaran penelitian kepada pengurus pemuda remaja GPdI Hebron-Malang.Penelitian yang dilakukan menggunakan metode kualitatif dengan pendekatan deskriptif dan eksegesis. Dari hasil penelitian kemudian didapat bahwa sebagian pengurus belum sepenuhnya memiliki citra diri yang dimaksudkan dalam Kejadian 1:26-27. Dari segi rohani, citra diri mereka rendah dengan persentase 36,5\%, kemudian dari segi psikologi persentase yang didapatadalah $45,9 \%$ dan dari segi sosial hasilnya adalah $55,5 \%$.
\end{abstract}

Kata Kunci: citra diri, pemuda, remaja, Kejadian 1:26-27

\section{PENDAHULUAN}

Ungkapan populer yang menyatakan bahwa manusia diciptakan menurut gambar dan rupa Allah pada dasarnya diambil dari Kejadian 1:26. Kata "gambar" di dalam bahasa Ibraninya memakai kata / fî (selem), sedangkan di dalam bahasa Yunani memakai kata eikon tou geou (eikon tou Theou). Adapun bahasa Latin untuk istilah ini adalah Imago Dei, yang berarti Allah menciptakan manusia mirip dengan sifat-Nya sendiri (Kej. 1:26-27) (Siringo-ringo, 2013, p. 39). Hal ini menunjuk kepada adanya kesamaan-kesamaan yang dimiliki antara Allah dan manusia dalam hal karakter, sifat, dan kualitasnya. Jadi, diciptakan menurut "gambar dan rupa Allah" dapat diartikan sebagai "dijadikan serupa dengan Allah."

Sebagai pembawa citra diri Allah, manusia pada dasarnya mewarisi seluruh sifat, karakter dan
kualitas-Nya. Citra diri Allah ini seharusnya nyata dalam kehidupan semua orang percaya, termasuk pemuda dan remaja. Namun pada kenyataannya tidaklah demikian, masa muda dianggap merupakan masa di mana seseorang menjadi gamang dan belum mengenal jati dirinya. Dinamika kehidupan pemuda biasanya ditandai dengan masa kebimbangan untuk menentukan arah perjalanan hidupnya, masa yang paling berpotensi namun penuh pergumulan, masa mencari jati diri atau citra diri. Di usia ini mereka cenderung berpendirian keras dan fanatik, memiliki cara beriman yang individual-reflektif, dalam artian mereka cenderung untuk menyatakan iman dengan menekankan kepada pengalaman, pengertian, dan pemahaman dirinya sendiri (Sidjabat, 2014, p. 265). Secara sosial, mereka sering membandingkan dirinya dengan orang lain, tidak dapat menerima peno- 
lakan, tidak mampu menerima kelebihan orang lain, gampang merasa curiga dan diperdaya orang lain. Hal ini terjadi tidak lepas dari cara mereka memandang dirinya. Bagaimana seseorang memandang dirinya atau yang disebut juga dengan citra diri merupakan salah satu krisis yang paling dominan di masa ini, karena pada masa ini adalah masa pencariaan identitas.

Citra diri yang baik memampukan seseorang untuk mengerti siapa dirinya sehingga ia akan dapat mengendalikan dengan baik berbagai macam keadaan yang mungkin akan dialaminya. Namun tidak demikian bagi seseorang yang memiliki citra diri yang buruk. Ia memandang dirinya lemah, merasa tidak berdaya, tidak mampu berbuat sesuatu, tidak kompeten, gagal, malang, tidak disukai sehingga kemudian dapat berujung kepada kehilangan daya tarik terhadap kehidupan (Sidjabat, 2011, p. 58). Jika hal ini tidak segera ditangani akan memberi dampak, antara lain: dari segi rohani, ia tidak mudah mempercayai dengan sepenuh hati kebaikan, kasih dan pertolongan Tuhan, menganggap Tuhan tidak adil dan kejam ketika masalah datang, cenderung melemparkan tanggung jawab, menuduh orang lain, dan akhirnya menyimpan akar pahit. Kemudian dari segi psikologi, seseorang dengan citra diri buruk cenderung merasa kuatir, takut menghadapi hari depan, merasa tidak memiliki kemampuan atau potensi, tidak mampu memutuskan secara benar yang dilakukannya, tidak mampu mengontrol diri dalam bertindak. Sementara dari segi sosial, ia memiliki perasaan malu secara berlebihan, tidak berani tampil di depan umum, menganggap diri tidak layak sehingga sulit untuk bersosialisasi dengan baik.

Ada beberapa faktor yang mempengaruhi citra diri, yang akan dibahas lebih lanjut dalam tulisan ini. Namun, faktor yang pertama dan utama dalam pembentukan citra diri seseorang adalah relasi dengan Tuhan. Akan sangat sulit menghadapi gejolak kehidupan bila seseorang tidak memiliki dasar yang kokoh dalam iman dan mengenal Allah dengan benar (Sidjabat, 2008, p. 36). Faktor lainnya adalah pola asuh orang tua dan pengaruh sosial. Citra diri yang tidak terbentuk dengan baik akan menimbulkan krisis pada diri seseorang.

Krisis citra diri dapat melanda siapa saja, termasuk orang percaya. Setidaknya itu terlihat pada sebagian pengurus pemuda dan remaja GPdI Hebron Malang, tempat penelitian ini dilakukan. Berdasarkan observasi awal yang dilakukan penulis terhadap pengurus pemuda dan remaja di sana, didapati: pertama, dari segi rohani pengurus pemuda dan remaja kurang memiliki hubungan yang intim dengan Tuhan. Ini terlihat dari kurangnya mereka mengikuti doa-doa dan persekutuan ibadah yang diadakan, tidak memiliki waktu pribadi dengan Tuhan, kurang memiliki kesadaran untuk membaca Alkitab setiap hari. Kedua, dari segi psikologi, pemuda dan remaja di sana masih kuatir dalam menghadapi masa depan, tidak berani bersaksi, tidak maksimal dalam mengunakan talenta yang mereka miliki untuk melayani Tuhan. Ketiga, bila dilihat segi sosial, ada beberapa pengurus pemuda dan remaja merasa minder untuk bergaul karena keadaan ekonomi keluarga. Penerimaan terhadap teman-teman yang baru juga terlihat kurang, bahkan sebagian tidak mau membuka diri dan bergaul. Jika hal-hal di atas dibiarkan maka pengurus pemuda remaja terancam tidak bertumbuh dalam kerohanian, mereka akan menjadi pribadi yang tidak mampu menghargai dan mempergunakan karunia yang ada pada diri mereka dan menjadi pribadi yang tidak peka sehingga tidak dapat menjadi berkat bagi sesamanya.

Pertanyaan utama yang hendak dijawab dalam penelitian ini adalah seperti apakah citra diri manusia menurut Kejadian 1:26-27 dan bagaimana pengurus Pemuda Remaja GPdI Hebron Malang mengaplikasikannya? Sesuai dengan judul "Citra Diri Manusia Menurut Kejadian 1:26-27 dan Aplikasinya bagi Pengurus Pemuda dan Remaja GPdI "Hebron" Malang" maka tujuan penelitian ini adalah mendeskripsikan citra diri manusia menurut Kejadian 1:2627, dan mendeskripsikan citra diri pengurus pemuda dan remaja GPdI "Hebron" Malang menurut Kejadian 1:26-27 


\section{METODE}

Penelitian dilakukan dengan menggunakan metode bersifat kualitatif dengan pendekatan deskriptif. Artinya, data dan fakta yang dihimpun lebih berbentuk kata atau gambar daripada angka-angka. Mendeskripsikan yang dimaksud di sini berarti menggambarkan apa, mengapa, dan bagaimana suatu kejadian terjadi (Satori dan Komariah, 2010, p. 28). Selain itu, penulis juga menggunakan metode eksegesis, yang dapat dipahami sebagai cara sistematis untuk menafsirkan sebuah teks. Metode ini mempelajari Alkitab secara sistematis dan teliti untuk menemukan arti asli yang dimaksudkan penulis sesuai konteks historis dan literalnya (Musvosvi dan Muchemwa, 2017, p. 29).

Penelitian dilakukan dalam dua tahapan dalam pengumpulan data, yaitu: pengumpulan data awal dan pengumpulan data utama. Pengumpulan data awal dilakukan melalui observasi, yaitu metode pengamatan yang mengharuskan peneliti turun ke lapangan mengamati hal-hal yang berkaitan dengan subyek penelitian. Sementara metode pengumpulan data utama yang digunakan dalam penelitian ini, yaitu melalui wawancara kepada pengurus pemuda dan remaja GPdI Hebron Malang. Pencatatan sumber data utama ini merupakan hasil gabungan dari kegiatan melihat, mendengar dan bertanya. Untuk mengumpulkan data, peneliti melakukan wawancara terstandar (standardized interview) atau wawancara terstruktur (structured interview) dan wawancara terbuka kepada partisipan dengan tujuan mencari jawaban atas pertanyaan yang diajukan. Peneliti kemudian mengumpulkan, memilah-milah, mengklasifikasikan dan mensintesiskan hasil wawancara untuk kemudian membuat kategori data yang diperoleh agar memiliki makna, mencari dan menemukan pola dan hubungan-hubungan, dan membuat temuan-temuan umum.

Beberapa hal yang menjadi keterbatasan dari penelitian ini adalah: penelitian ini adalah penelitian kualitatif dengan pendekatan deskriptif sehingga tidak dapat digeneralisasikan, ada kemungkinan partisipan memberikan jawaban atau informasi yang ti- dak jujur atau berbeda dengan tujuan penelitian ini, sehingga maksud penelitian ini tidak dengan maksimal. Selain itu, keterbatasan informasi data yang kurang akurat dapat menjadikan tujuan dari penelitian ini kurang maksimal.

Tempat penelitian adalah di GPdI Hebron Malang. Wadah pemuda dan remaja di GPdI Hebron Malang merupakan salah satu wadah selain wadah wanita, wadah pria, wadah sekolah minggu, dan wadah usimas yang terdapat di dalam gereja tersebut. Wadah pemuda dan remaja berada di bawah naungan depertemen pemuda yang beranggotakan kurang lebih 100 orang, dengan jumlah pengurus sebanyak 15 orang. Ibadah pemuda dan remaja dilakukan setiap minggu pada hari Sabtu pukul 17.00 WIB dengan jumlah partisipan sekitar 50-60 orang. Pemuda dan remaja memiliki program-program tersendiri yang mereka susun. Wadah pemuda dan remaja juga memiliki persekutuan yang dibagi menjadi 2 kelompok, yaitu kelompok sel (komsel) Yohanes dan kelompok sel (komsel) Yakobus yang diadakan setiap hari Selasa.

Partisipan pengumpulan data ini adalah pengurus pemuda dan remaja GPdI Hebron Malang. Peneliti membagikan wawancara terstruktur kepada 15 pengurus pemuda dan remaja, tetapi yang kembali sebanyak 12 sedangkan 3 lainnya mengalami keterlambatan dalam pengumpulan, maka peneliti menganggap 3 partisipan tersebut gagal dan tidak diikutsertakan dalam penghitungan hasil wawancara.

Data yang terkumpulkan kemudian dikelompokkan sesuai dengan rumusan dan dideskripsikan sesuai dengan urutan rumusan masalah tersebut. Adapun tiga pengelompokan hasil wawancara dikelompokkan menjadi: citra diri pengurus pemuda dan remaja GPdI Hebron ditinjau dari segi rohani, citra diri pengurus pemuda dan remaja GPdI Hebron ditinjau dari segi psikologi, dan citra diri pengurus pemuda dan remaja GPdI Hebron ditinjau dari segi sosial. Hasil yang diperoleh kemudian diolah dan disimpulkan dalam bentuk tabel lalu dideskripsikan. Untuk menganalisis hasil wawancara peneliti meng- 
gunakan teknik persentase dengan rumus sebagai berikut:

$$
\frac{n}{N} \times 100 \%
$$

Penjelasan rumus.

$\mathrm{n}=$ Jumlah jawaban yang diberikan partisipan

$\mathrm{N}=$ Jumlah Partisipan

$\%=$ Persentase

\section{HASIL DAN PEMBAHASAN}

\section{Citra Diri Manusia Menurut Kejadian 1:26-27}

Kitab Kejadian menyatakan dengan jelas bagaimana Allah yang berdaulat menciptakan manusia dengan berbagai keunggulan dan dengan penuh kasih menempatkannya dalam suatu situasi yang ideal (Hill dan Walton, 2004, p. 149). Kitab ini ditulis dengan tujuan untuk memberikan umat perjanjian Allah suatu pemahaman mendasar tentang diri-Nya, ciptaan, umat manusia, kejatuhan, kematian, penghakiman, perjanjian dan janji penebusan melalui keturunan Abraham.

\section{Eksegesis Kejadian 1:26-27}

Ayat 26 dimulai dengan kata "Berfirmanlah Allah," “yh Da/ r ma (wä (wayō'mér 'Ělōhîm). Frasa ini merupakan gabungan dari kata kerja bentuk qal imperfek orang ketiga maskulin tunggal, (berkata) dengan awalan penghubung (waw), yang berarti "dan." Secara harafiah kata ini (wăyyō'mér) berarti "dan ia berkata" atau "lalu berkatalah ia." Ia yang berkata di sini menunjuk kepada 'Ělōhîm (Allah). Kemudian kata "kita" dalam frasa "baiklah Kita menjadikan" adalah hf [ hl: (naaseh) merupakan kata kerja Qal imperfek dengan kata ganti orang pertama jamak, yang ditandai dengan akhiran posesif (נו - nu) (https:// biblehub.com/text/genesis/1-26.htm). Kata kerja Qal merupakan kata kerja Ibrani yang paling lazim dan mendasar dari semuanya, yang menyatakan tindakan atau status keberadaan yang sederhana. Kata kerja ini tidak mengindikasikan isyarat sebab akibat maupun kekhususan, namun digunakan dalam suatu pengertian cohortative, yang umumnya menyatakan permohonan, dorongan diri, keinginan, dan hasrat. Bentuk imperfek orang pertama dalam kata ini dipakai untuk menyatakan suatu pengharapan, suatu permohonan atau dorongan pribadi (tindakan-tindakan yang diinginkan si pembicara). Untuk kata ini, terjemahan NKIJ, NIV menggunakan kata make, yang artinya "membuat." Kata ini memakai verb (to do) artinya "yang akan dilakukan." Jadi, kata let us make adalah: "marilah Kita akan melakukan." Arti ini sama dengan dalam bahasa aslinya "marilah kita akan menjadikan."

Henry (2014, p. 23) meyakini kata "Kita" dalam penciptaan manusia merujuk kepada ketiga pribadi dalam Allah Trinitas: Bapa, Anak, dan Roh Kudus. Di dalam ayat ini Allah sedang berbicara kepada diri-Nya sendiri yang berkenaan dengan kesempurnaan kuasa dan hakekat ilahi yang Ia miliki. Jadi, ayat ini menunjukkan aktivitas Allah Tritunggal dalam penciptaan.

Dalam proses penciptaan manusia sendiri digunakan kata yang lain, yaitu ar B' (bara) yang berbentuk singular/tunggal. Kata ini adalah kata yang digunakan secara spesifik hanya untuk Allah saja. Jadi, manusia ada karena Allah yang menciptakan-Nya, bukan karena ada dengan sendiri atau seperti teori yang dikemukakan oleh Dariwin dan lainlain.

Kata Ibrani untuk "gambar kita" adalah Whml CB (betsal'mênû), yang terbentuk dari kata depan be dan kata sélèm ("Hebrew Thoughts", https://www. studylight.org). Kata ini dipakai untuk mendeskripsikan ukiran berbentuk binatang atau manusia (Hoekema, 2008, p. 18). Ketika diaplikasikan pada penciptaan manusia di dalam Kejadian 1, kata sělěm ini mengindikasikan bahwa manusia menggambarkan Allah atau dengan kata lain manusia merupakan suatu representasi Allah. Sedangkan kata Ibrani untuk "rupa," (demût) di dalam Kejadian 1 bermakna "menyerupai." Maka dengan demikian, "menurut gambar dan rupa" dapat diartikan sebagai "gambar yang menyerupai.” Menurut Hoekema (2008, p. 18), kedua kata tersebut, baik sělěm maupun demût, mengindikasikan bahwa manusia menggambarkan Allah, 
artinya manusia merupakan representasi Allah. Kedua kata tersebut pada dasarnya tidak menggambarkan dua entitas yang berbeda sebab baik kata tselem dan demuth seringkali digunakan secara bergantian. Bila kata tselem lebih menekankan kepada fisik maka kata demuth lebih cenderung mengacu kepada aspek etis dari gambar ilahi. Namun pada dasarnya kedua kata tersebut dapat dipandang sebagai sinonim di mana yang kedua menekankan yang pertama.

Pengertian segambar dan serupa dengan Allah menunjuk pada adanya kesamaan-kesamaan antara Allah dan manusia dalam karakter, sifat dan kualitas. Hal itu menunjukkan bahwa manusia membawa "citra Allah" di dalam dirinya. Selain itu, diciptakan menurut gambar dan rupa Allah ini mengindikasikan bahwa manusia menggambarkan Allah, artinya manusia merupakan suatu representasi Allah dalam tiga aspek, antara lain intelektual (mencakup pikiran, memori, pengetahuan, kebijaksanaan, dll.), kebenaran (termasuk di dalamnya kekudusan, kesadaran, moralitas, keadilan, jiwa, dan kebaikan), dan kehendak (hubungan yang bebas dengan Allah, kebahagiaan, dan kebebasan memilih) (Jastram, 2004, 8-9). Kesimpulannya adalah representasi Allah dalam diri manusia berhubungan dengan aspek-aspek non fisik (rohani), karena "Allah adalah Roh" (Yoh. 4:24), Ia bukan materi (Enns, 2014, p. 42).

\section{Citra Diri Manusia}

Dalam pandangan Kartono (dikutip dalam Dayakisni dan Hudaniyah, 2003, p. 25) citra diri merupakan keseluruhan yang dirasakan seseorang mengenai dirinya sebagai individu, baik ego maupun hal-hal yang di dalamnya. Dengan kata lain, citra diri adalah gambaran seseorang mengenai dirinya sendiri, identitasnya, kemampuannya, dan harga dirinya. Citra diri merupakan imajinasi seseorang mengenai dirinya sendiri (Devya, 2015, p. 434)

Pemahaman tentang citra diri sebagai cara pandang manusia terhadap dirinya juga nampak dalam beberapa kisah di dalam Alkitab, antara lain: Pertama, kisah dua belas pengintai, yang diutus $\mathrm{Mu}-$ sa untuk menyelidiki tanah Kanaan. Setelah kemba- li, sepuluh orang di antaranya memberi laporan betapa luar biasanya tanah tersebut dan penduduk yang ada di dalamnya sehingga membuat mereka minder dan berkata, "dan kami lihat diri kami seperti belalang" (Bil. 13:33). Ungkapan ini menunjukkan bahwa kesepuluh orang ini memiliki citra diri yang negatif. Sedangkan dua orang pe-ngintai lainnya, yaitu Yosua Bin Nun dan Kaleb Bin Yefune mengambil sikap berbeda dengan mengatakan, "jika Tuhan berkenan kepada kita, maka ia akan membawa kita masuk ke negeri itu dan memberikannya kepada kita" (Bil. 14:8). Kedua pengintai yang berbeda ini memandang diri mereka dari sudut keberadaan Allah dalam hidup mereka. Ini adalah contoh citra diri positif. Kedua, kisah Naomi, yang mengalami berbagai pengalaman pahit sehingga kemudian ia menyebut dirinya sendiri "Mara," yang berarti "Yang Maha Kuasa telah banyak melakukan yang pahit padaku" (Rut 1:20). Pengalaman hidup dapat memberikan pengaruh yang besar bagaimana seseorang memandang dirinya. Kisah Naomi ini merupakan contoh seseorang yang memiliki citra diri yang salah sebab ia mendasarkan atau memandang dirinya dari pengalaman hidup yang dialaminya (Sidjabat, 2011, p. 52). Ketiga, kisah Mefiboset, anak dari Saul. Daud mencari Mefiboset untuk mengembalikan segala harta milik ayahnya dan nenek moyangnya Saul. Namun, Mefiboset memandang dirinya tidak layak karena ia seorang yang cacat. Hal ini terlihat dari perkataannya: "apakah hambamu ini sehingga engkau menghiraukan anjing mati seperti aku?" (2 Sam. 9:8). Kisah Mefiboset ini juga menjadi kisah contoh citra diri negatif karena ia mendasarkan penilaian dirinya dari sudut pandang keberadaan fisiknya. Keempat, kisah perempuan Samaria. Pada masa Perjanjian Baru orang Samaria dipandang sebagai orang yang berdosa di mata orang Yahudi pada saat itu. Karena itu ketika Yesus berbicara dengan seorang perempuan Samaria, ia menjawab Yesus dengan mengatakan, "masakan Engkau seorang Yahudi minta minum kepadaku sebagai seorang Samaria" (Yoh. 4:9). Ungkapan ini menunjukkan bahwa perempuan ini menilai dirinya menurut persepsi orang terhadap dirinya, 
tetapi Yesus memandangnya dengan sudut pandang yang berbeda. Yesus melihat perempuan ini adalah seseorang yang berharga, layak untuk diselamatkan.

Dari beberapa contoh tersebut, terlihat bahwa pada dasarnya citra diri yang ada dalam diri manusia ada dua jenis, yaitu citra diri positif dan citra diri negatif. Seseorang yang memiliki citra diri positif adalah ia yang merasa dirinya bagus, baik dalam hal penampilan fisik maupun dengan perasaan hati, pemikiran, dan perbuatan. Citra diri positif membuat seseorang memandang dirinya sebagai orang yang bahagia, optimis, mampu mengontrol diri dan memiliki berbagai kemampuan. Citra diri yang positif memang memungkinkan seseorang untuk dapat bertahan menghadapi masalah yang mungkin saja muncul. Akan tetapi, citra diri positif belum tentu alkitabiah dan dapat menjerumuskan seseorang kepada kesombongan atau terlalu yakin dengan dirinya sendiri. Orang percaya seharusnya realitis dan bersandar kepada apa kata Alkitab dalam membentuk pendapat tentang diri sendiri. Citra diri yang positif dan alkitabiah adalah melihat diri kita dengan sudut pandang Alkitab atau sudut pandang Allah.

Kebalikan dari citra diri positif adalah citra diri negatif, citra diriyang meyakini dan memandang dirinya lemah, tidak berdaya, tidak dapat berbuat sesuatu, tidak kompeten, gagal, malang, tidak menarik, tidak disukai. Citra diri semacam inimembuat seseorang kehilangan daya tarik terhadap kehidupandan kesempatan yang dihadapinya. Citra diri negatif juga menyita energi dan kekuatan seseorang untuk berhubungan dengan orang lain karena energinya terhisap oleh ketidakmemadaian dirinya. Citra yang buruk atau negatif juga akan mempengaruhi seluruh aspek kehidupan orang tersebut sehingga ia akan mengalami kesulitan dalam menjalani hidup ini. Orang yang memiliki citra diri buruk cenderung melakukan apa yang disebut perendahan ganda. Ia merendahkan diri dengan berharap orang lain akan meninggikannya atau akan merendahkan orang lain agar bisa meninggikan dirinya. Jelaslah, citra diri semacam ini sama sekali tidak alkitabiah.
Pada dasarnya citra diri dipengaruhi oleh beberapa faktor, antara lain: pertama, hubungan dengan Allah. Pengenalan akan Allah membuat seseorang mengerti posisinya di hadapan Allah (Nee, 1993, p. 34). Orang percaya adalah anak Allah (Yoh. 1:12,13), yang diciptakan menurut gambar dan rupaNya (Kej. 1:26-27), dan yang oleh karena iman di dalam Kristus telah dinyatakan benar (Rm. 5:1). Dengan memilikipengenalan tentang Allah yang benar, seseorang akan memiliki citra diri yang benar juga, karena ia tahu Allah mengasihinya dan akan tetap mengasihinya. Kedua, peran orang tua. Orang tua dan orang-orang serumah atau keluarga inti adalah kelompok atau unit yang pertama-tama menanggapi perilaku saat seorang bayi lahir yang kemudian turut membentukcitra diri anak tersebut (Gunarsa dan Gunarsa, 1993, p. 105). Segala sanjungan, senyuman, pujian, dan penghargaan akan menyebabkan penilaian positif seseorang terhadap dirinya. Sedangkan ejekan, cemooh dan hardikan akan menyebabkan penilaian yang negatif terhadap dirinya (Turansky dan Miller, 2006, p. 16-17). Selain membawa citra Allah dalam dirinya, setiap anak membawa "citra diri atau gambar dan rupa" ayah dan ibu atau orang-orang yang sudah memeliharanya (significant others). Orang tua perlu menyadari bahwa anak membawa sifat genetis dari orang tua bahkan leluhurnya, yang dapat mempengaruhi kondisi dan perkembangan serta kecenderungan genetis atau jasmaninya. Ketiga, peranan sosial. Persepsi seseorang tentang dirinya, tidak terlepas dari struktur, peran, dan status sosial yang disandang orang tersebut. Struktur, peran, dan status sosial merupakan gejala yang dihasilkan dari adanya interaksi antar individu, individu dengan kelompok dan kelompok dengan kelompok. Individu yang memiliki status sosial yang tinggi cenderung memiliki citra diri yang lebih positif dibandingkan individu yang memiliki status sosial rendah.

\section{Hubungan Citra Diri Manusia Menurut Kejadian 1:26-27 Terhadap Citra Diri Seseorang}

Berikut penulis akan menguraikan beberapa alasan mengapa manusia harus memandang dirinya 
dengan benar dan apa saja bentuk aplikasinya dalam kehidupan sehari-hari: pertama, dari segi rohani Roh Allah yang berdiam di dalam diri manusia menjadikan manusia sebagai cerminan dari diri Allah sendiri. Keberadaan Roh Allah ini menunjukkan bahwa manusia memiliki kekuatan sekaligus kelemahan. Dikatakan sebagai kekuatan karena roh dapat menopang orang yang patah semangat (Ams. 18:14) serta menyelamatkan orang-orang yang remuk jiwanya (Mzm. 34:19). Disebut sebagai kelemahan karena jika Allah mengambil roh ini dari manusia, ia tidak dapat berbuat apa-apa atau kembali menjadi debu (Ayb. 34:14-15; 104:29-30). Manusia satu-satunya makhluk yang dibentuk dari tangan Allah sendiri dan dihembusi nafas-Nya (Kej. 2:7), bahkan penciptaan manusia dapat terjadi setelah melalui pertimbangan Allah dan ketetapan-Nya (Kej. 1:26) (Berkhof, 2004, p. 6). Semua kemampuan dan potensi manusia pada hakikatnya berasal dari Roh Allah sehingga manusia dapat hidup mengingini yang baik dan berperilaku serta bertindak yang benar. Oleh sebab itu, aplikasi yang nyata dari kesadaran akan hal ini antara lain: kesadaran bergantung kepada Allah, tidak lagi mengandalkan diri sendiri, selalu mengucap syukur, memiliki waktu pribadi dengan Tuhan, mempergunakan dan mengembangkan potensi dan kemampuannya untuk melayani Tuhan, dapat mengampuni, serta mencerminkan hidup sebagai anakanak Allah.

Kedua, dari segi psikologi manusia mewarisi sifat-sifat pribadi Allah dalam pikiran, perasaan dan kehendaknya. Maksud rasio atau pikiran di sini bukanlah sekadar daya manusia untuk berpikir logis atau kemampuan untuk bernalar, membandingkan, menilai dan menata, melainkan juga sebagai organ atau kemampuan untuk mengenal kebenaran (Thiessen, 2010, p. 27). Kemudian soal perasaan, yang kerap dikaitkan dengan hati karena perasaan bersumber dari hati itu sendiri, merupakan respons terhadap tindakan, situasi dan kondisi baru, atau pertimbangan, yang mengakibatkan seseorang peka terhadap sesuatu. Perasaan yang diberikan oleh Allah kepada manusia sebagai cerminan atau citra diri-Nya adalah perasaan murni, nyaman, penuh kasih sayang, perasaan sukacita dan damai sejahtera. Kejatuhan manusia dalam dosa membuat perasaannya menjadi tidak seperti semula, perasaannya menjadi rusak. Namun, ketika seseorang percaya kepada Kristus maka perasaannya pun diubahkan sehingga dapat kembali seperti semula, penuh kasih dan sukacita. Kemudian penjelasan ketiga adalah soalkehendak.Hal ini berkaitan dengan perbuatan, sikap dan akhlak. Kehendak adalah keinginan atau kemauan untuk berbuat atau tidak berbuat sesuatu. Oleh sebab itu, anak Tuhan yang memiliki pemahaman yang benar akan hal ini akan menampakkan sikap-sikap sebagai berikut: tidak lagi memikirkan hal-hal yang kotor atau buruk, mempercayai Tuhan dengan sepenuh hati, tidak mengambil keputusan berdasarkan perasaan, menjalani hidup yang layak di hadapan Tuhan, menundukkan kehendaknya di bawah kehendak Tuhan, tidak lagi berbuat sesuka hati dan menyepelekan dosa.

Ketiga, dari segi sosial. Sosialitas manusia merupakan bagian dari warisan diciptakan segambar dan serupa dengan Allah. Allah Tritunggal adalah Allah yang memiliki relasi persekutuan yang begitu sempurna di dalam diri-Nya. Sejak mula ketiga pribadi Allah, yakni: Allah Bapa, Allah Anak, dan Allah Roh Kudus sudah saling mengasihi dan memiliki persekutuan yang indah dan mesra (Thiessen, 2010, p. 240). Ketuhanan adalah gambaran sebuah relasi atau hubungan antara Bapa, Anak dan Roh Kudus sebagai tiga pribadi dalam satu. Secara alamiah manusia mewarisi relasi atau hubungan ini sehingga hidup berkomunitas dan berelasi dengan orang lain menjadi salah satu kebutuhan mendasar manusia. Pemahaman yang benar akan hal ini dapat terlihat dalam aplikasi berikut: tidak lagi menyalahkan orang lain ketika mengalami masalah hidup, tidak lagi mengharapkan pujian, dan hidup dalam kasih.

\section{Citra Diri Pengurus Pemuda dan Remaja Menurut Kejadian 1:26-27}

Untuk mengukur sejauh mana pengurus pemuda remaja GPdI Hebron malang menerapkan citra diri menurut Kejadian 1:26-27 sebagaimana telah di- 
uraikan sebelumnya, penulis membagikan pertanyaan yang terbagi dalam tiga kategori sesuai pembahasan sebelumnya, yakni: segi rohani, segi psikologi, dan segi sosial. Pertanyaan-pertanyaan yang diajukan dalam semua kategori pada intinya bertujuan melihat sejauh mana sasaran menerapkan aplikasi nyata dalam ketiga katagori tersebut sebagaimana telah diuraikan sebelumnya.

\section{Ditinjau dari Segi Rohani}

Kuantifikasi hasil wawancara yang meninjau dari segi rohani tergambar dalam tabel berikut:

\begin{tabular}{|c|c|c|c|c|c|c|c|}
\hline \multirow[t]{2}{*}{ No } & \multirow[t]{2}{*}{ Pertanyaan } & \multicolumn{6}{|c|}{ Jawaban } \\
\hline & & Ya & $\%$ & Tidak & $\%$ & Kurang & $\%$ \\
\hline 1 & $\begin{array}{l}\text { Apakah pengurus pemuda dan remaja sudah } \\
\text { bergantung sepenuhnya kepada Allah? }\end{array}$ & 2 & 16,7 & - & - & 10 & 83,3 \\
\hline 2 & $\begin{array}{l}\text { Apakah pengurus pemuda dan remaja masih } \\
\text { sering mengandalkan diri sendiri? }\end{array}$ & 7 & 58,3 & 2 & 16,7 & 3 & 25 \\
\hline 3 & $\begin{array}{l}\text { Apakah pengurus pemuda dan remaja selalu } \\
\text { mengucap syukur? }\end{array}$ & 7 & 58,3 & - & - & 5 & 41,7 \\
\hline 4 & $\begin{array}{l}\text { Apakah pengurus pemuda dan remaja } \\
\text { memiliki waktu pribadi dengan Tuhan? }\end{array}$ & 3 & 25 & - & - & 9 & 75 \\
\hline 5 & $\begin{array}{l}\text { Apakah pengurus pemuda dan remaja sudah } \\
\text { mempergunakan potensi dan kemampuannya } \\
\text { untuk melayani Tuhan? }\end{array}$ & 6 & 50 & - & - & 6 & 50 \\
\hline 6 & $\begin{array}{l}\text { Apakah pengurus pemuda dan remaja sudah } \\
\text { mengembangkan setiap potensi dan } \\
\text { kemampuan yang dimilikinya? }\end{array}$ & 7 & 58,3 & - & - & 5 & 41,7 \\
\hline 7 & $\begin{array}{l}\text { Apakah pengurus pemuda dan remaja sudah } \\
\text { hidup saling mengampuni? }\end{array}$ & 9 & 75 & - & - & 3 & 25 \\
\hline 8 & $\begin{array}{l}\text { Apakah pengurus pemuda dan remaja sudah } \\
\text { menyerahkan hidupnya dipimpin Roh? }\end{array}$ & 1 & 8,3 & - & - & 11 & 91,6 \\
\hline 9 & $\begin{array}{l}\text { Apakah pengurus pemuda dan remaja sudah } \\
\text { mencerminkan hidup sebagai anak-anak } \\
\text { Allah? }\end{array}$ & 3 & 25 & - & - & 9 & 75 \\
\hline
\end{tabular}

Tabel 1. Kuantifikasi Hasil Wawancara Segi Rohani

Berdasarkan hasil wawancara di atas ditinjau dari segi rohani, citra diri pengurus pemuda dan remaja GPdI "Hebron" Malang dapat disimpulkan sebagai berikut: Pertama, Pengurus pemuda dan remaja GPdI "Hebron" Malang belum memiliki citra diri manusia yang benar tentang diciptakan segambar dan serupa dengan Allah karena sebagai makhluk rohani, mereka belum mampu memahami bahwa roh yang ada dalam dirinya adalah kekuatan sekaligus kelemahan bagi mereka. Hal ini terbukti dari hasil jawaban bahwa sebagian besar mereka, sebanyak $83,3 \%$ tidak bergantung sepenuhnya kepada Allah dan $16,7 \%$ lainnya masih kadang-kadang saja bergantung sepenuhnya kepada Allah. Untuk pertanyaan selanjutnya, apakah mereka masih mengandalkan kekuatannya sendiri, sebanyak $58,3 \%$ pemuda remaja menjawab mereka masih mengandalkan dirinya sendiri sementara 25\% lainnya menjawab kadang-kadang saja mereka mengandalkan dirinya sendiri dan selebihnya sebanyak $16,7 \%$ menjawab tidak mengandalkan diri sendiri. Kedua, sebagian dari pengurus pemuda dan remaja GPdI "Hebron" Malang sudah memahami bahwa diri mereka istimewa di hadapan Allah. Hal ini terlihat dari jawaban yang diberikan: sebanyak 58,3\% mengaku mereka selalu mengucap syukur dalam hidup mereka. Na- 
mun ketika ditanyakan tentang apakah mereka menyediakan waktu pribadi dengan Tuhan, ternyata hanya $25 \%$ saja yang memiliki waktu pribadi dengan Allah secara rutin. Sedangkan $75 \%$ pengurus pemuda dan remaja hanya kadang-kadang saja memiliki waktu pribadi dengan Allah. Ketiga, sebagian dari pengurus pemuda dan remaja GPdI "Hebron" Malang sudah memahami bahwa setiap potensi dan kemampuan yang dimilikinya berasal dari Allah. Hal ini terlihat dari jawaban di mana sebanyak 54,2\% sudah mengembangkan dan mempergunakan setiap potensi dan kemampuannya untuk melayani Tuhan. Sayangnya, sebagian lagi yaitu $45,8 \%$ masih belum sepenuhnya mengembangkan dan mempergunakan potensi yang mereka miliki untuk melayani Tuhan. Keempat, sebagian besar pengurus pemuda dan remaja GPdI "Hebron" Malang ternyata belum memahami bahwa hidup mereka sudah diselamatkan. Mes- kipun $75 \%$ di antaranya menjawab sudah hidup saling mengampuni, kehidupan saling mengampuni ini tidak dibarengi dengan penyerahan diri mereka untuk dipimpin oleh Roh Allah. Hal ini terlihat dari jawaban di mana hampir seluruh pengurus pemuda dan remaja, tepatnya 91,6\%, mengakui tidak sepenuhnya menyerahkan hidup mereka dipimpin oleh Roh Allah. Karena itu, mereka belum dapat mencerminkan kehidupan sebagai anak-anak Allah. Terlihat hanya sebagian kecil saja yang mengaku hidupnya sudah mencerminkan hidup sebagai anak-anak Allah, yaitu sebesar 25\%. Sedangkan $75 \%$ selebihnya merasa belum sepenuhnya mencerminkan hidup sebagai anak-anak Allah.

\section{Ditinjau dari Segi Psikologi}

Hasil wawancara tentang segi sosial yang dikuantifikasikan tergambar dalam tabel berikut:

\begin{tabular}{|l|l|c|c|c|c|c|c|}
\hline \multirow{2}{*}{ No } & \multicolumn{1}{|c|}{ Pertanyaan } & \multicolumn{5}{c|}{ Jawaban } \\
\cline { 3 - 7 } & \multicolumn{1}{|c|}{ Ya } & $\%$ & Tidak & $\%$ & Kurang & $\%$ \\
\hline 1 & $\begin{array}{l}\text { Apakah pengurus pemuda dan remaja } \\
\text { masih memikirkan hal-hal yang kotor atau } \\
\text { buruk? }\end{array}$ & 6 & 50 & 2 & 16,7 & 4 & 33,3 \\
\hline 2 & $\begin{array}{l}\text { Apakah remaja dan pemuda sudah } \\
\text { mempercayai Tuhan dengan sepenuh hati? }\end{array}$ & 7 & 58,3 & 3 & 25 & 2 & 16,7 \\
\hline 3 & $\begin{array}{l}\text { Apakah pengurus pemuda dan remaja } \\
\text { dalam mengambil keputusan mendasarkan } \\
\text { pada perasaan? }\end{array}$ & 6 & 50 & - & - & 6 & 50 \\
\hline 4 & $\begin{array}{l}\text { Apakah pengurus pemuda dan remaja } \\
\text { masih merasa bahwa dirinya tidak layak di } \\
\text { hadapan Tuhan? }\end{array}$ & 6 & 50 & 4 & 33,3 & 2 & 16,7 \\
\hline 5 & $\begin{array}{l}\text { Apakah pengurus pemuda dan remaja } \\
\text { sudah sepenuhnya menundukkan } \\
\text { kehendaknya dibawah kehendak Tuhan? }\end{array}$ & 4 & 33,3 & - & - & 8 & 66,7 \\
\hline 6. & $\begin{array}{l}\text { Apakah pengurus pemuda dan remaja } \\
\text { masih suka berbuat sesuka hatinya dan } \\
\text { menyelelekan dosa? }\end{array}$ & 6 & 50 & 1 & 8,3 & 5 & 41,6 \\
\hline
\end{tabular}

Tabel 2. Kuantifikasi Hasil Wawancara Segi Psikologi

Dari tabel di atas dapat disimpulkan: Pertama, Sebagian besar pengurus pemuda dan remaja GPdI "Hebron" Malang dari segi psikologi belum mampu mengontrol pikirannya. Hal ini terlihat 50\% mereka menjawab masih suka memikirkan hal-hal kotor dan buruk. Sedangkan 33,3\% lagi menjawab kadang-kadang masih memikirkan hal yang demikian. Namun untuk pertanyaan selanjutnya mengenai mempercayai Allah dengan sepenuh hati, 75\% mereka menjawab sudah mempercayai Allah dengan 
sepenuh hati mereka, sedangkan $16,7 \%$ menjawab kadang-kadang, dan 25\% lainnya menjawab tidak mempercayai Tuhan dengan sepenuh hatinya.

Kedua, Pengurus pemuda dan remaja GPdI "Hebron" Malang sebagian besar belum mampu mengontrol perasaannya. Hal ini terlihat bahwa 50\% dari antaramereka masih merasa dirinya tidak layak di hadapan Allah, sementara sebagian kecil di antaranya, yakni sebesar $16,7 \%$ terkadang merasa demikian. Hanya sekitar 33,3\% pengurus pemuda dan remajayang merasa dirinya layak dihadapan Allah. Hal itu mempengaruhi mereka ketika mengambil sebuah keputusan hidup di mana 50\% dari antara mereka mengambil keputusan berdasarkan perasaannya dan selebihnya pun kadang-kadang berbuat demikian. Pengurus pemuda dan remaja GPdI "Hebron" Malang sebagian besar belum mampu mengon- trol kehendaknya. Dari data yang terkumpul, 33,3\% pengurus pemuda dan remaja mengaku masih belum mampu menundukkan kehendaknya di bawah kehendak Allah. Sementara 66,7\% lagi masih kadangkadang saja mereka menundukkan kehendaknya di bawah kehendak Allah. Hal tersebut didukung dengan fakta bahwa 50\% dari antara mereka mengaku masih suka berbuat sesuka hatinya dan menyepelekan dosa. 41,6\% lagi masih melakukan hal yang sama, masih berbuat sesuka hatinya dan menyepelekan dosa. Hanya $8,3 \%$ saja yang mengaku tidak suka berbuat demikian lagi.

\section{Ditinjau dari Segi Sosial}

Hasil wawancara tentang segi sosial yang dikuantifikasikan tergambar dalam tabel berikut:

\begin{tabular}{|l|l|c|c|c|c|c|c|}
\hline \multirow{2}{*}{ No } & \multicolumn{1}{|c|}{ Pertanyaan } & \multicolumn{5}{c|}{ Jawaban } \\
\cline { 3 - 7 } & \multicolumn{1}{|c|}{$\begin{array}{l}\text { Ya } \\
\text { Apakah pengurus pemuda dan remaja masih } \\
\text { menyalahkan oranglain ketika masalah datang dalam } \\
\text { hidupnya? }\end{array}$} & 7 & 58,3 & 1 & 8,3 & 4 & 33,3 \\
\hline 2 & $\begin{array}{l}\text { Apakah pengurus pemuda dan remaja masih } \\
\text { membutuhkan pujian ketika telah melakukan } \\
\text { sesuatu? }\end{array}$ & 6 & 50 & 4 & 33,3 & 2 & 16,7 \\
\hline 3 & $\begin{array}{l}\text { Apakah pengurus pemuda dan remaja sudah hidup } \\
\text { dalam kasih, saling mengampuni dan saling } \\
\text { menguatkan? }\end{array}$ & 7 & 58,3 & 1 & 8,3 & 4 & 33,3 \\
\hline
\end{tabular}

Tabel 3. Kuantifikasi Hasil Wawancara Segi Sosial

Berdasarkan data di atas, ditinjau dari segi sosial, citra diri pengurus pemuda dan remaja GPdI "Hebron" Malang dapat disimpulkan sebagai berikut: Pertama, Pengurus pemuda dan remaja GPdI "Hebron" Malang sebagian besar masih belum mampu menyadari kesalahannya. Hal ini terlihat ketika masalah datang dalam hidupnya, mereka menyalahkan orang lain. Sekitar 58,3\% dari partisipan dengan presentase masih menyalahkan oranglain, $33,3 \%$ terkadang juga melakukan hal yang sama, hanya $8,3 \%$ saja yang tidak lagi menyalahkan orang lain ketika masalah datang dalam hidup mereka. Kedua, Ketika didata mengenai kemampuan menerima pujian dengan perasaan yang tidak berlebihan, sebanyak $50 \%$ dari pengurus pemuda remaja masih membutuhkan pujian dari orang lain ketika melakukan sesuatu, selebihnya sekitar $16,7 \%$ juga terkadang masih membutuhkan pujian, sedangkan 33,3\% lainnya mengaku tidak memerlukan pujian ketika melakukan sesuatu. Ketiga, Soal hidup dalam kasih, sebesar 58,3\% dari pengurus pemuda dan remaja GPdI "Hebron" Malang menjawab mereka sudah hidup saling mengampuni dan saling menguatkan. 33,3\% lainnya mengakui masih kadang-kadang saja mengampuni dan menguatkan. Hanya $8,3 \%$ saja yang masih belum hidup saling mengampuni dan saling menguatkan. 


\section{Interpretasi Data}

Setelah menganalisis data di atas, maka peneliti menyimpulkan bahwa pengurus pemuda dan remaja GPdI "Hebron" Malang belum sepenuhnya memiliki citra diri seperti yang dimaksudkan dalam Kejadian 1:26-27 tentang diciptakan segambar dan serupa dengan Allah. Jika dilihat dari data ditinjau dari segi rohani; mereka belum mampu memahami bahwa roh yang diberikan Allah dalam diri mereka adalah kekuatan sekaligus kelemahan, mereka belum mampu menyadari bahwa mereka istimewa di hadapan Allah, mereka belum sepenuhnya mengembangkan dan mempergunakan potensi dan kemampuannya untuk melayani Tuhan, mereka juga belum menyadari bahwa sebagai makhluk rohani mereka telah diselamatkan, sebagian lagi mengaku belum mampu hidup dalam kasih sebagaimana tergambar dari tabel di bawah ini:

\begin{tabular}{|l|l|c|c|}
\hline Fokus & \multicolumn{1}{|c|}{ Indikator } & Persentase & Kriteria \\
\hline \multirow{3}{*}{ Segi rohani } & $\begin{array}{l}\text { Mampu memahami bahwa roh yang ada di dalam dirinya adalah } \\
\text { kekuatan sekaigus kelemahan }\end{array}$ & $22,3 \%$ & $\begin{array}{c}\text { Sangat } \\
\text { Rendah }\end{array}$ \\
\cline { 2 - 4 } & Mampu memahami bahwa dirinya istimewa dihadapan Allah & $33,4 \%$ & Rendah \\
\cline { 2 - 4 } & $\begin{array}{l}\text { Mampu menyadari bahwa potensi dan kemampuan yang ada } \\
\text { dalam dirinya adalah pemberian Allah }\end{array}$ & $54,1 \%$ & Sedang \\
\cline { 2 - 4 } & Mampu menyadari bahwa hidupnya sudah diselamatkan & $36,1 \%$ & Rendah \\
\hline \multirow{2}{*}{$\begin{array}{l}\text { Segi } \\
\text { psikologi }\end{array}$} & Mampu mengontrol pikiran & $45,9 \%$ & Sedang \\
\cline { 2 - 4 } & Mampu mengontrol perasaan & $50 \%$ & Sedang \\
\cline { 2 - 4 } & Mampu mengontrol kehendaknya & $41,7 \%$ & Sedang \\
\hline \multirow{2}{*}{ Segi sosial } & Mampu menyadari kesalahannya & $58,3 \%$ & Sedang \\
\cline { 2 - 4 } & Mampu menerima pujian dengan tidak berlebihan & $50 \%$ & Sedang \\
\cline { 2 - 4 } & Mampu hidup dalam kasih & $58,3 \%$ & Sedang \\
\hline
\end{tabular}

Tabel 4. Intepretasi Data

Ditinjau dari segi psikologi, mereka juga belum mampu mengontrol pikiran, perasaan dan kehendaknya.Mereka masih cenderung memikirkan hal-hal yang kotor dan buruk, masih ada yang belum mempercayai Tuhan dengan sepenuh hati. Sebagian besar mereka masih memutuskan masalah dalam hidup mereka dengan mendasarkan pada perasaan, sebagian lagi merasa bahwa mereka belum layak di hadapan Tuhan. Sedangkan dalam kehendak, mereka belum mampu menundukkan kehendaknya di bawah kehendak Allah, mereka juga masih banyak yang masih berbuat sesuka hati dan menyepelekan dosa.

Ditinjau dari segi sosialnya, mereka juga belum memiliki citra diri manusia menurut Kejadian 1:26-27 tentang diciptakan segambar dan serupa dengan Allah sebagai makhluk sosial. Hal tersebut terlihat dari jawaban yang diberikan bahwa mereka belum mampu menyadari kesalahannya dan masih sering menyalahkan orang lain ketika masalah datang dalam hidup mereka, pujian menjadi hal yang penting bagi mereka sehingga, mereka masih membutuhkan pujian ketika melakukan sesuatu, selain itu mereka juga belum sepenuhnya hidup dalam kasih, saling mengampuni dan saling menguatkan.

\section{KESIMPULAN}

Berdasarkan hasil penelitian yang telah dilakukan dan hasil pembahasannya maka pada bab ini peneliti mencoba mengemukakan kesimpulan sebagai berikut: Pertama, Citra diri manusia menurut Kejadian 1:26-27 tentang diciptakan segambar dan serupa menunjuk pada adanya kesamaan-kesamaan antara Allah dan manusia, yaitu dalam karakter, sifat dan kualitasnya. Keistimewaan lainnya mengindikasikan bahwa manusia menggambarkan Allah, artinya manusia merupakan representasi Allah. Representasi 
adalah perbuatan, keadaan atau hal yang mewakili. Dalam hal ini manusia merepresentasikan Allah dalam setiap sifat, karakteristik dan kualitasnya. Ke$d u a$, Pengurus pemuda dan remaja GPdI "Hebron" Malang belum sepenuhnya memiliki citra diri manusia yang dimaksudkan dalam Kejadian 1:26-27 sehingga tercerminkan lewat sikap hidup mereka dan mencerminkan citra diri yang negatif.

Berdasarkan penelitian yang sudah dilakukan maka peneliti merasa perlu memberi saran-saran kepada pihak-pihak yang terkait sebagai berikut: Pertama, Bagi Gereja. Gereja diharapkan lebih memperhatikan pemuda dan remaja dengan memberikan perhatian dan pembinaan khusus, seperti memberikan khotbah-khotbah dan seri-seri pendalaman Alkitab berkenaan dengan pembentukan karakter, yang dapat membawa mereka lebih mengenal diri atau pribadi mereka menurut sudut pandang Alkitab atau sudut pandang Allah. Kedua, Pengurus pemuda dan Remaja. Pengurus pemuda dan remaja hendaknya meningkatkan intensitas hubungannya dengan Tuhan, mengikuti sei-seri pendalaman Alkitab tentang pembentukan citra diri, membaca firman Tuhan setiap hari. Dengan demikian mereka memiliki citra diri yang benar, sehingga mampu

\section{DAFTAR RUJUKAN}

"Genesis 1:26. "https://biblehub.com/text/genesis/126.htm. Diakses 24 Oktober 2018

"Hebrew Thoughts", https://www.studylight.org/ language-studies/hebrew-thoughts.html? article $=592$. Diakses 20 Oktober 2018.

Berkhof, Louis. 2004. Teologi Sistematika 2: Doktrin Manusia. Surabaya: Momentum.

Dayakisni dan Hudaniyah. 2003. Psikologi Sosial Edisi Revisi. Malang: UMM Pres.

Devya. 2015. "Hubungan Citra Diri dan Perilaku Konsumtif pada Remaja Putri yang Memakai Kosmetik Wajah". eJournal Psikologi, 3 (1): 433-440, (http://ejournal.psikologi.fisipunmul.ac.id/site/wp-content/uploads/2015/ 03/eJOURNAL\%20PSIKOLOGI\%20(03- memberi teladan bagi seluruh anggota pemuda dan remaja. Ketiga, Pemuda dan remaja. Sebagai pembawa citra diri Allah, mereka perlu diberi pemahaman khusus tentang citra diri manusia yang sesuai dengan Alkitab, sehingga mereka mampu memandang dirinya sebagaimana Allah memandang diri mereka, mereka mampu menggembangkan dan mempergunakan setiap potensi dan kemampuan yang sudah Allah berikan kepada mereka untuk melayani Tuhan. Keempat, Orang tua. Orang tua memiliki peranan yang penting dalam pendidikan dan pembinaan karakter anak-anak sebagai pemegang mandat langsung dari Allah. Mandat ini akan berhasil jika orang tua memiliki pengetahuan yang benar tentang citra diri manusia yang sesuai Alkitab dan mereka berkewajiban untuk mengajarkannya kepada anakanak mereka. Untuk itu, orang tua sendiri sepatutnya sudah lebih dahulu hidup dalam kebenaran dan memiliki pemahaman yang benar tentang prinsip-prinsip pendidikan yang alkitabiah sehingga dapat mendidik anak-anak mereka dengan penuh kasih, disiplin, dan menerima mereka seperti Kristus menerima mereka. Orang tua juga harus menjadi teladan bagi anak-anak mereka.

02-15-03-13-23).pdf), diakses 22 Oktober 2018.

Gunarsa, Singgih D. dan Gunarsa, Yulia Singgih D. 1999. Psikologi Praktis: Anak, Remaja dan Keluarga. Jakarta: BPK Gunung Mulia.

Hoekema, Anthony A. 2008. Manusia: Ciptaan Menurut Gambar Allah. Surabaya: Momentum.

Jastram, Nathan. 2004. "Man as Male and Female: Created in the Image of God". Concordia Theological Quarterly, 68 (1): 5-95.

Musvosvi, Joel dan Muchemwa, Stella. 2017. "Exegesis of Paul's Writings: A Literal and Pragmatic Approach to Philippians 3:12-14". IOSR Journal of Humanities and Social Science (IOSR-JHSS), 22 (7): 29-34. 
Nee, Watcman. 1994. Manusia Rohani. Surabaya: Yayasan Pekabaran Injil.

Samarena, D. 2017. "Berteologi Dalam Konteks Indonesia Modern". Evangelikal: Jurnal Teologi Injili dan Pembinaan Warga Jemaat, 1 (1): 19-28.

Satori, Djaman dan Komariah, Aan. 2010. Metodologi Penelitian Kualitatif. Bandung: Alfabeta.

Sidjabat, B.S. 2008. Membesarkan Anak dengan Kreatif: Panduan menanamkan Iman \& Moral Kepada Anak Sejak Dini. Yogjakarta: ANDI.
Sidjabat, B.S. 2011. Membangun Pribadi yang Unggul.Yogjakarta: ANDI.

Sidjabat, B.S. 2014. Pendewasaan Manusia Dewasa: Pedoman Pembinaan Warga Jemaat Dewasa Dan Lanjut Usia. Bandung: Kalam Hidup.

Siringo-ringo, V. M. 2013. Theologi Perjanjian Lama. Yogyakarta: ANDI.

Thiessen, Henry C. 2010. Teologi Sistematika. Malang: Gandum Mas.

Turansky, Scott dan Miller, Joanne. 2006. Menjadi Orang Tua Kristen. Jakarta: Nafiri Gabriel. 